\title{
СРАВНИТЕЛЬНЫЙ АНАЛИЗ СОДЕРЖАНИЯ КИСЛОТЫ АСКОРБИНОВОЙ В ЦВЕTКАХ CALENDULA OFFICINALIS L., ПРОИЗРАСТАЮЩЕЙ В ОРЕНБУРГСКОЙ ОБЛАСТИ
}

\section{COMPARATIVE ANALYSIS \\ OF THE CONTENT OF ASCORBIC ACID IN THE FLOWERS OF CALENDULA OFFICINALIS L. GROWING IN DIFFERENT DISTRICTS OF THE ORENBURG REGION}

\section{Tarenkova \\ N. Vinokurova \\ A. Bondarenko \\ A. Sinegovets \\ I. Mikhailova}

Summary. The aim of this work is a comparative analysis of the content of ascorbic acid in the flowers of Calendula officinalis L. growing in different climatic conditions in the Orenburg region. The method of redox titration established that the largest amount of ascorbic acid is contained in the flowers of Calendula officinalis $L$. harvested in Sharlyksky and Ponomarevsky districts $(1.030 \pm 0.1 \%$ and $0.686 \pm$ $0.08 \%$, respectively), which can be explained by the climatic conditions of the growth of Calendula officinalis $\mathrm{L}$.

Keywords: Calendula officinalis L., material of medicinal plants, ascorbic acid, Orenburg region.

\section{Введение}

alendula officinalis L. - однолетнее травянистое растение семейства Астровые (Asteraceae), распространено повсеместно на территории Российской Федерации, в том числе и в Оренбургской области. Спектр применения Calendula officinalis L. определяется наличием биологически активных веществ (БАВ), среди которых значительный вклад в суммарное терапевтическое действие вносит кислота аскорбиновая.
Таренкова Ирина Валерьевна

Ассистент, Оренбургский государственный медицинский университет, Оренбург itarenkova@mail.ru

Винокурова Наталья Викторовна К.б.н., доцент, Оренбургский государственный медицинский университет, Оренбург

nschustova@mail.ru

Бондаренко Анатолий Игоревич

Аспирант, Оренбургский государственный медицинский университет, Оренбург, Россия anat1998bond@mail.ru

Синеговец Ангелина Анатольевна Ассистент, Оренбургский государственный медицинский университет, Оренбург a.a.sinegovets@yandex.ru

Михайлова Ирина Валерьевна Д.б.н., Оренбургский государственный медицинский университет, Оренбург michaylova74@yandex.ru

Аннотация. Целью работы явился сравнительный анализ содержания кислоты аскорбиновой в цветках Calendula officinalis L., произрастающей в различных климатических условиях на территории Оренбургской области. Методом окислительно-восстановительного титрования установлено, что наибольшее количество кислоты аскорбиновой содержится в цветках Calendula officinalis L., заготовленных в Шарлыкском и Пономаревском районах $(1,030 \pm 0,1 \%$ и 0,686 $\pm 0,08 \%$ соответственно), что может быть объяснено климатическими условиями произрастания Calendula officinalis $\mathrm{L}$.

Ключевые слова: Calendula officinalis L., лекарственное растительное сырьё, кислота аскорбиновая, Оренбургская область. 
Таблица 1. Климатическая характеристика районов Оренбургской области

\begin{tabular}{|c|c|c|c|c|c|}
\hline Районы & $\begin{array}{l}\text { Коли-чество } \\
\text { осад-ков, } \\
\text { мм/год }\end{array}$ & $\begin{array}{l}\text { Географиче-ское } \\
\text { располо-жение }\end{array}$ & $\begin{array}{l}\text { Характерис-тика } \\
\text { климата }\end{array}$ & $\begin{array}{l}\text { Средне-годовая } \\
\text { температура, }{ }^{\circ} \mathrm{C}\end{array}$ & $\begin{array}{l}\text { Высота над } \\
\text { уровнем моря, } \\
\text { м }\end{array}$ \\
\hline Шарлыкский & $350-400$ & Северо-запад & $\begin{array}{l}\text { Континен- } \\
\text { тальный }\end{array}$ & $+2,4$ & 190 \\
\hline Пономарёвский & 414 & Северо-запад & $\begin{array}{l}\text { Резко континен- } \\
\text { тальный }\end{array}$ & $+2,3$ & 169 \\
\hline Сакмарский & 343 & Центр & $\begin{array}{l}\text { Резко континен- } \\
\text { тальный }\end{array}$ & $+3,9$ & 111 \\
\hline Кваркенский & $265-315$ & Северо-восток & $\begin{array}{l}\text { Резко континен- } \\
\text { тальный }\end{array}$ & $+1,5$ & 281 \\
\hline Тюльганский & 352,63 & $\begin{array}{l}\text { Север центральной } \\
\text { части }\end{array}$ & Континен-тальный & $+3,1$ & 308 \\
\hline Оренбургский & 375 & Центр & $\begin{array}{l}\text { Умеренно-континен- } \\
\text { тальный }\end{array}$ & $+4,7$ & 107 \\
\hline Беляевский & 320 & Центр & $\begin{array}{l}\text { Резко континен- } \\
\text { тальный }\end{array}$ & $+3,9$ & 128 \\
\hline Адамовский & $306-320$ & Восток & $\begin{array}{l}\text { Резко континен- } \\
\text { тальный }\end{array}$ & $+1,5$ & 284 \\
\hline
\end{tabular}

антитоксическое действие при отравлении многими ядами и бактериальными токсинами [8]. Исследования показывают, что накопление БАВ, в т.ч. кислоты аскорбиновой, зависит от природно-климатических факторов, таких как количество осадков, температуры воздуха, высоты над уровнем моря районов произрастания растений, рельефа местности, химического состава почвы [9].

В настоящее время все чаще возникает потребность в поиске перспективных регионов для культивирования лекарственного сырья с максимальным содержанием действующих веществ. Исходя из вышеизложенного, представляет актуальность изучение содержания кислоты аскорбиновой в цветках Calendula officinalis $L .$, произрастающей в различных климатических условиях на территории Оренбургской области.

Целью настоящего исследования явился сравнительный анализ содержания кислоты аскорбиновой в цветках Calendula officinalis L., произрастающей в различных районах Оренбургской области.

\section{Материалы и методы исследования}

Объектами исследования явились цветки Calendula officinalis L., собранные в восьми районах Оренбургской области в период максимального накопления БАВ во время цветения в местах вдали от города, автомобильных и железных дорог, промышленных предприятий, отстойных сооружений [3], а также в качестве сырья сравнения сырьё Calendula officinalis L., приобретённое в аптечной сети.
Выбор районов обусловлен климатическими характеристиками (таблица 1).

Количественное определение содержания кислоты аскорбиновой в исследуемом ЛРС производили методом окислительно-восстановительного титрования [2].

Содержание кислоты аскорбиновой в пересчете на абсолютно сухое сырье в процентах (X) вычисляли по формуле (1):

$$
X=\frac{V \cdot 0,000088 \cdot 300 \cdot 100 \cdot 100}{\mathrm{a} \cdot(100-W)}
$$

где: 0,000088 - количество кислоты аскорбиновой, соответствующее 1 мл раствора 2,6-дихлорфенолиндофенолята натрия (0,001 моль/л), в граммах;

$V$ - объем раствора 2,6-дихлорфенолиндофенолята натрия (0,001 моль/л), пошедшего на титрование, в миллилитрах;

$a$ - навеска сырья в граммах;

$W$ - потеря в массе при высушивании сырья в процентах [1], [2].

Результаты проведенных исследований обработаны с использованием пакета программ для ПК «Microsoft Excel 2016», «STATISTICA 10.0», включая метод непараметрического (критерий Манна-Уитни) анализа.

\section{Результаты исслеАования}

Количественное определение содержания кислоты аскорбиновой в цветках Calendula officinalis L., произрастающей в некоторых районах Оренбургской 


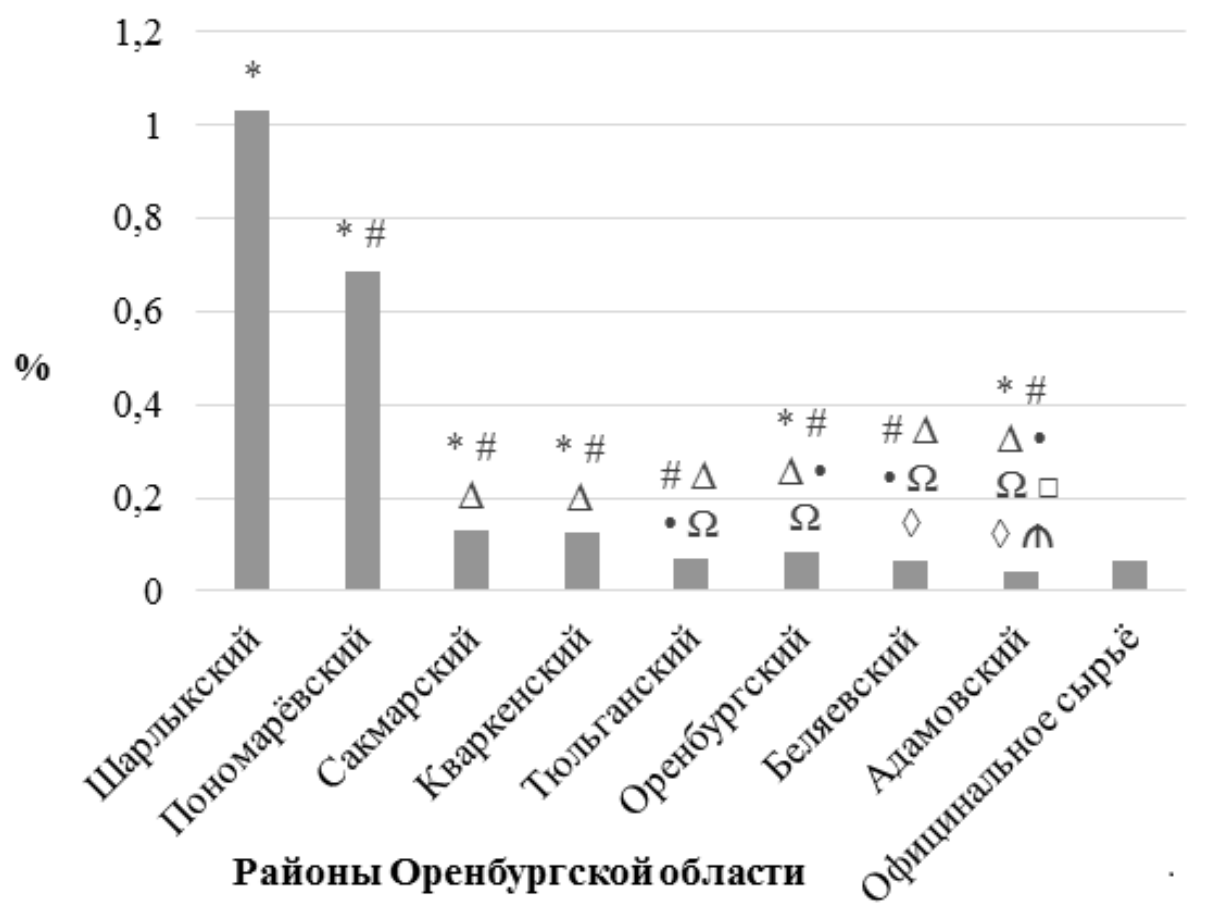

Рис. 1. Содержание кислоты аскорбиновой в цветках Calendula officinalis L.

Примечание: достоверные различия $(p<0,05):{ }^{*}$ - по сравнению с официнальным сырьём;

\# - по сравнению с цветками Calendula officinalis L. (далее - ЛP), произрастающими в Шарлыкском

районе; $\Delta$ - по сравнению с цветками ЛР, произрастающими в Пономарёвском районе;

- - по сравнению с цветками ЛР, произрастающими в Сакмарском районе; $\Omega$ - по сравнению

с цветками ЛР, произрастающими в Кваркенском районе; $\square-$ по сравнению с цветками ЛР,

произрастающими в Тюльганском районе; $\diamond$ - по сравнению с цветками ЛР, произрастающими

в Оренбургском районе; $\pitchfork$ - по сравнению с цветками ЛР, произрастающими в Беляевском районе.

области, показало, что по сравнению с официнальным сырьём цветки Calendula officinalis L., произрастающие в Шарлыкском, Пономарёвском, Сакмарском, Кваркенском, Тюльганском и Оренбургском районах, накапливают кислоту аскорбиновую в более высоких концентрациях (рисунок 1). Наибольшее накопление кислоты аскорбиновой отмечается в цветках Calendula officinalis L., собранных в Шарлыкском и Пономаревском районах, $1,030 \pm 0,104 \%$ и 0,686 $\pm 0,079 \%$ соответственно, а наименьшее - в цветках, собранных в Ада-

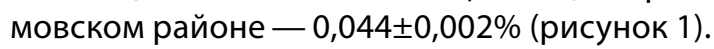

Анализ количественного содержания кислоты аскорбиновой в цветках Calendula officinalis L., произрастающей в различных районах Оренбургской области, установил, что содержание кислоты аскорбиновой различно в зависимости от района произрастания растения. Количественное содержание кислоты аскорбиновой можно выразить следующей последовательностью: Шарлыкский > Пономарёвский > Сакмарский > Кваркенский > Оренбургский > Тюльганский > Беляевский > Адамовский.

\section{Обсужление}

Обсуждая полученные результаты, установленные различия по содержанию кислоты аскорбиновой в исследуемом сырье можно объяснить, с одной стороны, тем, что определяющим фактором накопления кислоты аскорбиновой в растениях могут являться осадки. Отмечено, что обильные дожди негативно влияют на содержание данного витамина в растениях, поскольку избыток влаги препятствует накоплению кислоты аскорбиновой. При этом оптимальная обеспеченность солнечной энергией и оптимальное увлажнение растений обеспечивают сохранность в них кислоты аскорбиновой [5], [7]. Осадки на территории Оренбургской области распределяются неравномерно. Их среднее количество убывает с северо-запада (450 мм в год) на восток (260 мм в год), тем самым определяя более высокое содержание кислоты аскорбиновой в цветках Calendula officinalis L., собранной в Шарлыкском районе на северо-западе области и низкое содержание в восточных Адамовском и Кваркенском районах. Тем самым, в цветках Calendula officinalis L., собранных 
в северо-западных районах Оренбургской области, кислоты аскорбиновой должно содержаться существенно больше, чем в сырье, заготовленном на востоке области [6], что подтверждается полученными нами данными.

С другой стороны, существует также зависимость концентрации кислоты аскорбиновой от высоты местности произрастания растений над уровнем моря. По мере увеличения высоты местности произрастания происходит повышение содержания кислоты аскорбиновой в данных растениях. Факторами, определяющими закономерности накопления кислоты аскорбиновой, являются понижение температуры и повышение уровня ультрафиолетовой радиации [4]. Однако, согласно проведенным исследованиям, этот фактор не является определяющим, поскольку высота над уровнем моря на территории одного района также может варьироваться, ввиду особенностей рельефа (горы, низменности, холмы, возвышенности и т.д.). К примеру, в нашем исследовании наименьшее содержание кислоты аскорбиновой отмечено в Адамовском районе $(0,044 \pm 0,002 \%)$, который отличается значительной высотой над уровнем моря (284 м), в то время как в Кваркенском районе, также существенно возвышающемся над уровнем моря (281 м), содержание кислоты аскорбиновой оказывается несколько большим $(0,127 \pm 0,008 \%)$.

Следовательно, полученные данные подтверждают необходимость системного учёта влияния всех факторов, воздействующих на произрастающее растение и определяющих накопление кислоты аскорбиновой.

\section{Эак^ючение}

Таким образом, исследования показали, что Шарлыкский и Пономарёвский районы являются наиболее благоприятными районами Оренбургской области для заготовки цветков Calendula officinalis L., что можно объяснить наиболее благоприятными климатическими условиями данных районов, способствующими накоплению биологически активных веществ в цветках Calendula officinalis $L$.

\section{ЛИТЕРАТУРА}

1. Беликов В.Г. Фармацевтическая химия. В 2 ч.: Ч. 1. Общая фармацевтическая химия; Ч. 2. Специальная фармацевтическая химия: Учебник для вузов / В.Г. Беликов. - М.: МЕДпресс-информ, 2007. - 624 с.

2. Государственная фармакопея Российской Федерации. В 3 т. / Министерство здравоохранения Российской Федерации. 14 изд. [Электронный реcypc].— URL: http://femb.ru/femb/pharmacopea.php (дата обращения 25.11.2020)

3. Куркин В.А. Фармакогнозия: Учебник для студентов фармацевтических вузов / В.А. Куркин. — Самара: 000 «0форт» СамГмУ, 2004. - 1180 с.

4. Новрузов А.Р. Содержание и динамика накопления аскорбиновой кислоты в плодах ROSA CANINA L. / A.P. Новрузов // Химия растительного сырья.2014. 一 № 3.—C. 221-226.

5. Овчаров К.Е. Витамины растений / К.Е. Овчаров. - М.: Колос, 2009.-328 с.

6. Плешков Б.П. Биохимия сельскохозяйственных растений / Б.П. Плешков.; под ред. доктора химических наук, академика ВАСХнИЛ В.М. Клечковского.- М.: Колос, 1965.- 447 с.

7. Смирнов М.И. Витамины / М.И. Смирнов. - М.: Медицина, 1999. - 56 с.

8. Третьяков Н.Н. Физиология и биохимия сельскохозяйственных растений / Н.Н. Третьяков, Е.И. Кошкин, Н.М. Макрушин. - М.: Колос, 2000.- 180 с.

9. Чупахина Г.Н. Система аскорбиновой кислоты растений: монография / Г.Н. Чупахина. — Калининград, 1997. - 120 с.

10. Яковлева Г.П. Лекарственное растительное сырьё. Фармакогнозия / Г.П. Яковлева, К.Ф. Блинова. — Спб.: СпецЛит, 2004. - 765 с.

(c) Таренкова Ирина Валерьевна ( itarenkova@mail.ru ), Винокурова Наталья Викторовна ( nschustova@mail.ru ), Бондаренко Анатолий Игоревич ( anat1998bond@mail.ru), Синеговец Ангелина Анатольевна ( a.a.sinegovets@yandex.ru ),

Михайлова Ирина Валерьевна ( michaylova74@yandex.ru).

Журнал «Современная наука: актуальные проблемы теории и практики» 